Egyptian Journal of Aquatic Biology \& Fisheries

Zoology Department, Faculty of Science,

Ain Shams University, Cairo, Egypt.

ISSN $1110-6131$

Vol. 23(5): 81- 87 (2019)

www.ejabf.journals.ekb.eg

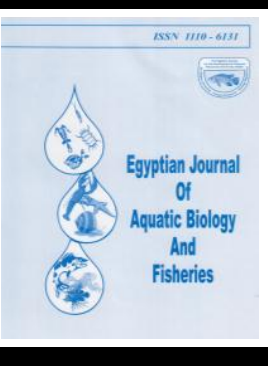

\title{
Monitoring water quality and plankton distribution in the River Nile around El-Maadi area in Egypt during 2018
}

\author{
Sayed Rashad ${ }^{1}$, Muhammad Abdul Moneem ${ }^{2}$, Ghadir A. El-Chaghaby ${ }^{1 *}$ and \\ Shereen F. Abdel-Kader ${ }^{1}$ \\ 1- Regional Center for Food and Feed, Agricultural Research Center, Giza, Egypt \\ 2- El-Fostat Laboratory, Cairo Water Company, Cairo, Egypt \\ Corresponding author : ghadiraly@yahoo.com
}

\begin{abstract}
Keywords:
River Nile

El-Maadi

Algae

Diatoms

Plankton

Egypt
\end{abstract}

ARTICLE INFO

Article History:

Received: Oct. 7, 2019

Accepted: Nov. 28,2019

Online: Dec. 2019

\begin{abstract}
In the present study, water quality parameters and planktons distribution were monitored monthly during the year 2018 within a segment of the Nile around El-Maadi area in Cairo, Egypt. The results indicated a temperature variation ranging from $16.8^{\circ} \mathrm{C}$ in January to $29.4^{\circ} \mathrm{C}$ in July. The $\mathrm{pH}$ of water recorded a value around 8.2 all over the study period. Total dissolved solids were highest in January $(346.5 \mathrm{mg} / \mathrm{l})$ whereas, the lowest value was obtained in July $(240.3 \mathrm{mg} / \mathrm{l})$. The water electric conductivity ranged from 528 to 365 $\mu \mathrm{S} / \mathrm{cm}$. Very little variations were noticed for ammonia, nitrite and nitrate concentrations with maximum values in November being $0.40,0.06$ and $0.605 \mathrm{mg} / \mathrm{l}$, respectively. The calcium concentrations ranged from 27.0 to $37.2 \mathrm{mg} / \mathrm{l}$, magnesium concentrations were in the range from 10.32 to 16.4 $\mathrm{mg} / \mathrm{l}$, whereas iron concentrations varied from 0.09 to $0.325 \mathrm{mg} / \mathrm{l}$ and manganese concentrations range was 0.0001 to $0.192 \mathrm{mg} / \mathrm{l}$. The results indicated that the total algae count was highest during winter season followed by autumn then spring and summer. The results showed that during winter season the count of blue green algae was maximum (385 cell $/ \mathrm{ml}$ ) and also the number of diatoms was highest in winter. Pearson's correlation analysis revealed positive correlation for the total number of algae and turbidity, total dissolved solids (TDS), electroconductivity (EC) and calcium $(\mathrm{Ca})$ in water. Whereas, there was a strong negative correlation for the total algae count and water temperature.
\end{abstract}

\section{INTRODUCTION}

The River Nile is the main and most important source of fresh water in Egypt and thus monitoring water quality of the River Nile is a fundamental goal.

In an optimal scenario, water quality should be evaluated using physical, chemical and biological parameters to provide a full spectrum of data for suitable water management; however, this requires much more time and expenses, thus the study of biological parameters is widely accepted to provide reliable information about water quality (Singh et al., 2013).

Nile system chemical and physical components affect water quality and could be good indicators of water pollution and pollutant sources (Ali et al., 2014).

Chemical analyses of water provide a good indication of the quality of aquatic systems; however, they do not integrate ecological factors and do not necessarily reflect the ecological status of the system (Ali and Ahlam, 2017). 
The word "Plankton" is a collective term used to describe all those organisms whose movement power is insufficient to prevent water currents from moving them. Planktons are used as indicators of water quality in different ways.

The quality of water is essentially determined by the quantity of algae, specially eutrophic waters (Kutama et al., 2014).

Planktons have a short life span and react rapidly to modifications in the environment, thus providing early warning signs of declining circumstances may be a helpful measure for determining water quality (El-kassas and Gharib, 2016).

Several researchers took the density and variety of phytoplankton as biological indicators to evaluate the quality of water and the degree of eutrophication (Yang et al., 2008).

The objective of the present study was to investigate plankton algae distribution in relation to chemical and physical properties change of water over one year (2018) period along a segment of the River Nile near El-Maadi area in Cairo, Egypt.

\section{MATERIALS AND METHODS}

\section{Water Sampling}

Samples were collected from different sites along the Nile River around El_Maadi area in Cairo, Egypt on a monthly sampling routine. The sampling was done following the EPA sampling guidelines (EPA, 2008).

\section{Water chemical and physical analysis}

Water samples were analyzed to determine the temperature, turbidity, dissolved oxygen, $\mathrm{pH}$, electric conductivity, total dissolved solids, total hardness, anions and cations. The water analysis was carried out using the procedures of the standard methods of analysis of water and wastewater (APHA, 2000).

\section{Plankton collection and identification}

Planktons were collected using plankton net of mesh size $70 \mu \mathrm{m}$. The net was lowered gently and immersed into the water at a distance of $2 \mathrm{~m}$ for 3 minutes at constant speed. Samples were fixed with 4\% Lugol's solution to preserve the phytoplankton. On coming to the laboratory, the collected phytoplankton samples were condensed by centrifugation and were enumerated. The procedures adopted for plankton collection and identification were as described in the Standard Operating Procedure for Phytoplankton Analysis (US Environment Protection Agency and Usepa, 1994) and "How to Know the Fresh-Water Algae" by Evans and Prescott, (1956).

\section{Statistical Analysis}

Pearson's correlation analysis was computed using "SPSS 19 software" to assess the relations between algae count and other water quality parameters.

\section{RESULTS AND DISCUSSION}

\section{Water physio-chemical characteristics}

The physiochemical parameters recorded for water samples monthly in the study area during 2018 were summarized in Table (1).

The results of temperature measurements showed a variation ranging from $16.8^{\circ} \mathrm{C}$ in January to $29.4^{\circ} \mathrm{C}$ in July. Temperature can vary widely and is influenced by a number of variables including geographic location, shading, water source, thermal discharges, water body size and depth. It is important because it has a great influence on what organisms can survive in a water body ; it can directly affect the 
amount of oxygen that can be dissolved in water ; the rate of photosynthesis of algae and larger aquatic plants ; the metabolic rates of aquatic organisms ; and the sensitivity of organisms to toxic wastes, parasites and diseases(Uttah et al., 2010).

The results revealed that there were no clear observed variations for the $\mathrm{pH}$ of water in the study area all over the year 2018 and the recorded $\mathrm{pH}$ values were around 8.2 to 8.3 . The $\mathrm{pH}$ of a river is usually influenced by its age, geology as well as the type and composition of discharged water that the river receives. The $\mathrm{pH}$ is important for aquatic life and even a small $\mathrm{pH}$ change can be harmful to species that are sensitive to $\mathrm{pH}$ (Uttah et al., 2010).

The total content of all compounds dissolved in water either inorganic or organic is expressed as Total dissolved solids (TDS). Values of TDS higher than 2000 $\mathrm{mg} / \mathrm{l}$ have been reported to exert negative impact on aquatic species (Alexandru and Cuza, 2014). In the present study, the values of TDS varied along the studied period and ranged a highest value in January $(346.5 \mathrm{mg} / \mathrm{l})$ and lowest value in July $(240.3 \mathrm{mg} / \mathrm{l})$.

The Electric conductivity (EC) value is proportionally dependent on the TDS value with high EC values indicating high salt content in water (Ibraheem et al., 2015). The recorded EC values for the water samples in the study area showed a minimum value of $365 \mu \mathrm{S} / \mathrm{cm}$ in June and maximum value $528 \mu \mathrm{S} / \mathrm{cm}$ in December.

The turbidity level recorded in the present study showed little monthly variations and were in the range (from 9.71 to $11.90 \mathrm{NTU}$ ).Water turbidity is an important water quality indicator. It is affected by several factors such as geology, farming, urban development operations, and occurrences of topography, vegetation, and precipitation (APHA, 1992). High particulate matter levels can result in enhanced sedimentation and siltation in a stream, which in turn can destroy significant fish habitat regions and other aquatic life (Perera et al., 2015).

Table 1: Physico-chemical quality parameters of water

\begin{tabular}{|c|c|c|c|c|c|c|}
\hline \multirow[b]{2}{*}{ Month } & \multicolumn{6}{|c|}{ Measured Parameter } \\
\hline & Turbidity (NTU) & Temperature $\left({ }^{\circ} \mathbf{C}\right)$ & TDS (mg/l) & $\mathrm{EC}(\boldsymbol{\mu S} / \mathbf{c m})$ & pH & DO (mg/l) \\
\hline January & 11.05 & 16.8 & 346.5 & 443 & 8.2 & 8.4 \\
\hline February & 11.90 & 19.8 & 304.4 & 523 & 8.3 & 10.1 \\
\hline March & 10.10 & 20.8 & 275.1 & 418 & 8.2 & 8.1 \\
\hline April & 11.40 & 24.9 & 258.3 & 392 & 8.3 & 8.1 \\
\hline May & 10.21 & 28.7 & 266.5 & 404 & 8.3 & 8.2 \\
\hline June & 9.71 & 26.9 & 242.8 & 365 & 8.3 & 8.0 \\
\hline July & 9.11 & 29.4 & 240.3 & 368 & 8.3 & 8.3 \\
\hline August & 9.92 & 29.1 & 247.5 & 372 & 8.3 & 8.0 \\
\hline September & 10.43 & 27.9 & 275.1 & 412 & 8.3 & 8.6 \\
\hline October & 10.40 & 26.2 & 287.5 & 436 & 8.3 & 8.5 \\
\hline November & 10.89 & 24.9 & 303.8 & 460 & 8.3 & 7.9 \\
\hline December & 11.69 & 20.3 & 346.1 & 528 & 8.3 & 7.9 \\
\hline
\end{tabular}

It has to be noted that nitrate and nitrite in drinking water can have negative human health impacts, while ammonium is not of direct importance for human health (Schullehner et al., 2017). Figure (1) illustrates the variation of the concentrations of inorganic nitrogen species $\left(\mathrm{NH}_{3}, \mathrm{NO}_{2}\right.$ and $\left.\mathrm{NO}_{3}\right)$ during the study period. Very little variations were noticed for ammonia concentrations with maximum values in November being 0.40, 0.06 and $0.605 \mathrm{mg} / \mathrm{l}$, respectively. 


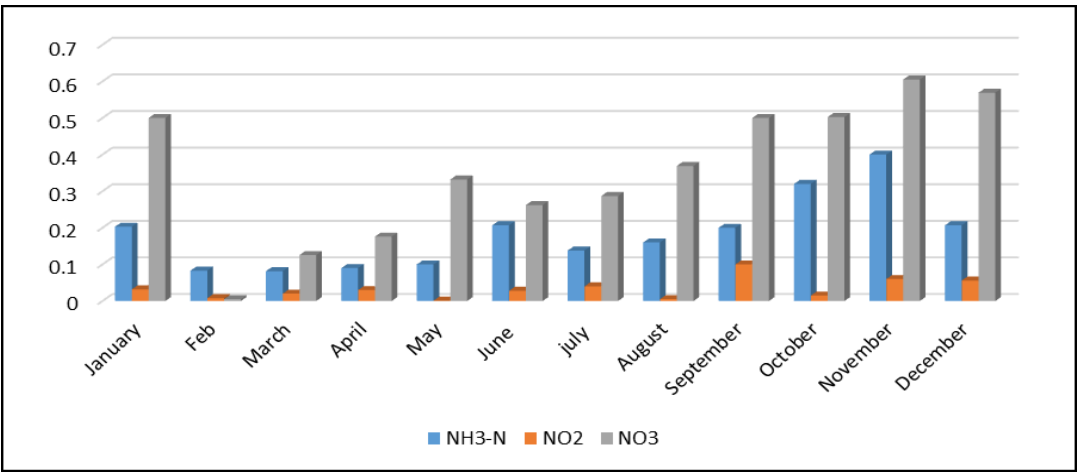

Fig. 1: Monthly variation in nitrogen species concentration in water (mg/l).

The monthly variation of calcium, magnesium, iron and manganese were recorded as depicted in Figure (2) and Figure (3). The calcium concentrations ranged from 27.2 to $37.0 \mathrm{mg} / \mathrm{l}$, magnesium concentrations were in the range from 10.3 to 16.4 $\mathrm{mg} / \mathrm{l}$, whereas iron concentrations ranged from 0.09 to $0.33 \mathrm{mg} / \mathrm{l}$ and manganese concentrations range was 0.0001 to $0.192 \mathrm{mg} / \mathrm{l}$.

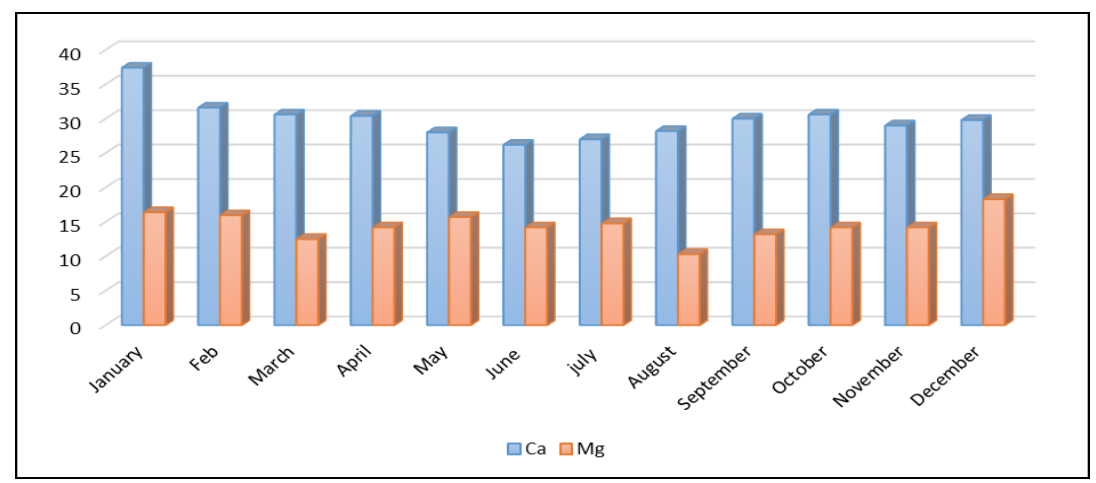

Fig. 2: Monthly variation in calcium and magnesium concentration in water (mg/l)

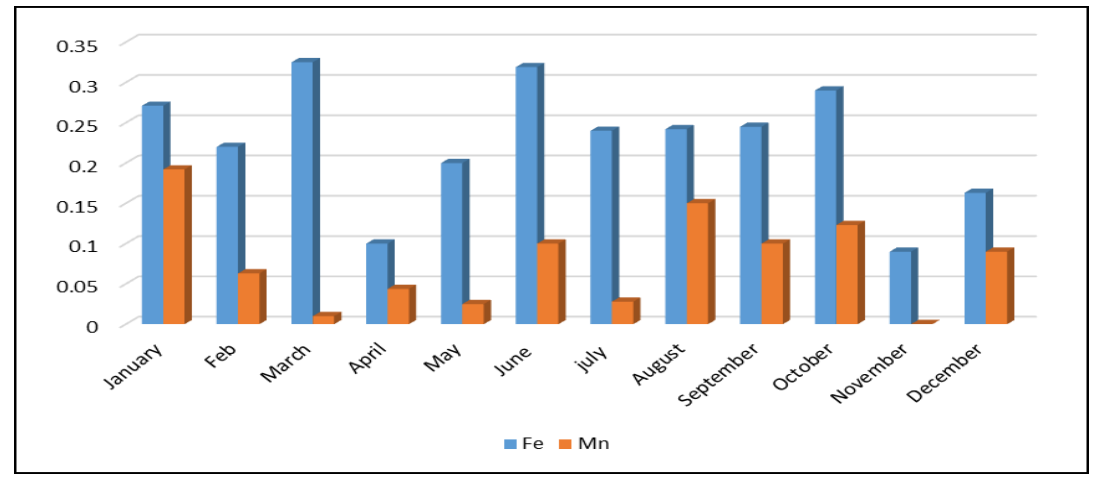

Fig. 3: Monthly variation in iron and manganese concentration in water $(\mathrm{mg} / \mathrm{l})$

\section{Algae distribution in water during 2018}

During the present study, the seasonal variations of algae densities in water samples were also monitored and the results are depicted in Figure (4). The count of diatoms, green, blue green algae, unicellular and filamentous algae and total algal count around the four seasons of 2018.

The results indicated that the total algae count was highest during winter season followed by autumn then spring and summer. The results showed that during winter season the count of blue green algae was maximum ( $385 \mathrm{cell} / \mathrm{ml})$ this may be attributed to the low temperature and alkaline $\mathrm{pH}$ of water during this season and to 
the fact that in this season the Nile comes with oxidizable organic matter that make good medium for algae growth (KM, 2014).

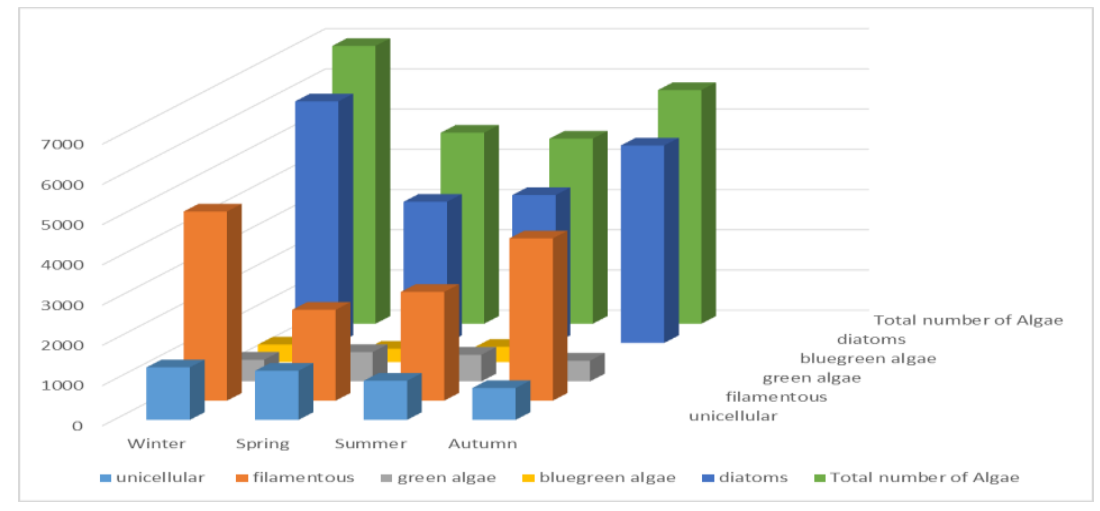

Fig. 4: Seasonal variation of algae count in water during 2018

Also the number of diatoms was highest in winter which agrees with previously reported studies where it was concluded that rainy season is the best period for diatoms to grow also diatoms have the ability to grow in different strength of sun light in addition the velocity of the flow affect the algae growth (KM, 2014).

\section{Correlation between total algae count and water physiochemical parameters}

Pearson's correlation was employed to investigate the relationship between total algae count and different physiochemical parameters of water. The data are presented in Table (2).

Table 2: Pearson's correlation of algae count and water physiochemical parameters

\begin{tabular}{|c|c|c|c|}
\hline Parameter & $\begin{array}{l}\text { Pearson's correlation } \\
\text { coefficient }(\mathbf{r})\end{array}$ & $\begin{array}{l}\text { Coefficient of } \\
\text { determination }\left(\mathbf{R}^{2}\right)\end{array}$ & p-value \\
\hline Turbidity & 0.5984 & 0.3581 & 0.039827 \\
\hline Temperature & -0.6997 & 0.4896 & 0.011425 \\
\hline TDS & 0.7641 & 0.5838 & 0.003811 \\
\hline EC & 0.7957 & 0.6331 & 0.001966 \\
\hline pH & 0.0786 & 0.0062 & 0.808155 \\
\hline $\mathbf{N H}_{3}-\mathbf{N}$ & 0.1423 & 0.0202 & 0.659093 \\
\hline $\mathrm{NO}_{2}$ & 0.3615 & 0.1307 & 0.248257 \\
\hline $\mathrm{NO}_{3}$ & 0.3146 & 0.099 & 0.319277 \\
\hline Total Hardness & 0.4706 & 0.2215 & 0.122575 \\
\hline $\mathbf{C a}$ & 0.5035 & 0.2535 & 0.122575 \\
\hline Mg & 0.4621 & 0.2135 & 0.130419 \\
\hline $\mathrm{Fe}$ & 0.0358 & 0.0013 & 0.912049 \\
\hline Mn & 0.3416 & 0.1167 & 0.277149 \\
\hline Dissolved Oxygen & 0.3789 & 0.0901 & 0.34327 \\
\hline
\end{tabular}

The results indicated moderate positive correlation between the algae count and water turbidity. This signifies that there is a tendency for high algae count scores go with high turbidity scores (and vice versa). The results were significant at $\mathrm{p}<0.05$.

On the other hands in contrarly to previous reports, the present study data showed a moderate negative correlation for the algae count and water temperature implying that there is a tendency for high algae count to go with low temperature (and vice versa). The results were significant at $p<0.05$.

A strong positive correlation with significant results $(\mathrm{p}<0.05)$ was obtained for the correlation between algae count and the two parameters TDS and EC of water.

The results also showed a moderate correlation between algae count and calcium in water although the results were non-significant $(\mathrm{p}>0.05)$. 


\section{CONCLUSION}

In conclusion, water quality parameters examined during the present study varied among the four seasons of 2018. Similarly, the total number of algae, diatoms, green, blue green algae, unicellular and filamentous algae showed seasonal variations. Regular monitoring of water physiochemical parameters as well as plankton abundance could be used as a good indicator for water quality assessment.

\section{REFERENCES}

Alexandru, U. and Cuza, I. (2014). Seasonal variation of water quality parameters in the Chirita Reservoir, IASI, Research Gate, 2013.

Ali, E. M. and Ahlam, E. S. (2017). Environmental Indices and Phytoplankton Community Structure as Biological

Indicators for Water Quality of the River Nile, Egypt. Egypt J. Aquat Biol Fish., 21:87-104.

Ali, E.M.; Shabaan-Dessouki, S.A.; Soliman, A.R.I. and Shenawy, S. E. (2014). Characterization of Chemical Water Quality in the Nile River, Egypt. Int J Pure \&Applied Biosci., 2:35-53.

American Public Health Association (APHA) (1985). Standard Methods for the Examination of Water and Wastewater. 16th Edition. American Public Health Association, Washington, D.C., New York. nd Management of Aquatic Ecosystems, 411: 06.

American public health association (APHA) (1989). Standard methods for the examination of water and wastewater, sewage and industrial wastes. 16th Edition. American Public Health Association, Washington, D.C., New York.

American Public Health Association (APHA) (1998). Standard methods for the examination of water and wastewater. $19^{\text {th }}$ Edition. American Public Health Association, Washington, D.C., New York.

American Public Health Association (APHA) (2005). Standard methods for the examination of water and wastewater. 21th Edition. American Public Health Association, American Water Works Association, Water Pollution Control Federation, Washington, D.C., New York.

Barinova, S. and Krupa, E. (2017). Bioindication of Ecological State and Water Quality by Phytoplankton in the Shardara Reservoir, Kazakhstan. Environment and Ecology Research, 5(2): 73-92.

Duncan, D.; Harvey, F.; Walker, M. and Australian Water Quality Centre (2007). EPA Guidelines: Regulatory monitoring and testing Water and wastewater sampling. www.epa.sa.gov.au

El-kassas, H.Y. and Gharib, S.M. (2016). Phytoplankton abundance and structure as indicator of water quality in the drainage system of the Burullus Lagoon, southern Mediterranean coast, Egypt. Environ Monit Assess.

Evans, R.I. and Prescott, G.W. (1956). How to Know the Fresh-Water Algae. Bull Torrey Bot Club., 83:311.

Ibraheem, A.M.; Mazhar, S.M.; Khan, N. and Ravikumar, A. (2015). Seasonal variation of groundwater quality in Veppanthattai block of Perambalur district, Tamilnadu-implements of the water quality index method. Available Online wwwjocprcom J Chem Pharm Res., 7:938-943. 
KM K. (2014). Seasonal Variation of Algae Types, Counts and Their Effect on Purified Water Quality Case Study: Al-Mogran and Burri Plants, Khartoum State,Sudan. J Biodivers Endanger Species, 02:2-5.

Perera, P.A.C.T. (2015). Sundarabarathy T V., Sivananthawerl T, Edirisinghe U. Seasonal variation of water quality parameters in different geomorphic Channels of the upper Malwathu Oya in Anuradhapura, Sri Lanka. Trop Agric Res., 25:158.

Schullehner, J.; Stayner, L. and Hansen, B. (2017). Nitrate, nitrite, and ammonium variability in drinking water distribution systems. Int $\mathbf{J}$ Environ Res Public Health, 14:1-9.

Singh, U.B.; Ahluwalia, A.S.; Sharma, C.; Jindal, R. and Thakur, R.K. (2013). Planktonic indicators: A promising tool for monitoring water quality (earlywarning signals). Ecol Environ Conserv, 19:793-800.

US Environment Protection Agency, Usepa. (1994). Standard Operating Procedure for Phytoplankton Analysis.

Uttah, E.; Uttah, C.; Akpa, P.; Ikpeme, E.; Ogbeche, J. Usip, L. and ASOR, J. (2010). Bio-survey of Plankton as indicators of water quality for recreational activities in Calabar River, Nigeria. J Appl Sci. Environ Manag, 12.

Yang, X.E.; Wu, X.; Hao, H.L. and He, Z.L. (2008). Mechanisms and assessment of water eutrophication. J Zhejiang Univ. Sci. B, 9:197-209. 